\title{
Application of Jute Geo Textiles (JGT) for Sustainable Management of Hill Slopes
}

\section{S Manivannan ${ }^{1}$, OPS Khola ${ }^{1}$, K Kannan ${ }^{1}$, V Kasthuri Thilagam ${ }^{1}$ and PK Choudhury ${ }^{2}$}

${ }^{1}$ ICAR - Indian Institute of Soil and Water Conservation, Regional centre, Tamil Nadu, India

${ }^{2}$ National Jute Board, Kolkata, India

*Corresponding Author: S Manivannan, ICAR - Indian Institute of Soil and Water Conservation, Regional centre, Tamil Nadu, India.

Received: April 24, 2019; Published: June 20, 2019

DOI: 10.31080/ASAG.2019.03.0537

\begin{abstract}
Permanent structures are being used traditionally to stabilize the slopes in hill region which is tedious and costly process. As the slope failure is result of land slide, mining, flood, etc, slope stabilization using permanent structures cannot be adopted in larger scale. Slope stabilization by establishing vegetation with the support of Jute Geotextiles is an alternative method for stabilization of slopes in hilly areas. Set of field studies have been conducted at ICAR- Indian Institute of Soil and Water Conservation (IISWC), Regional Centre, Udhagamandalam, Tamil Nadu, India with the objective to study the effect of various Jute Geotextiles (JGT) on runoff, soil loss, survival and growth of tea. The results shows that the 500 GSM Open Weave Jute Geotextiles is effective in reducing runoff (6.7 - 12.5\%), soil loss (3.93 $\left.\mathrm{t}^{-1} \mathrm{ha}^{-1} \mathrm{yr}^{-1}\right)$ and nutrient loss (46 - 62\%) and recommended for hill slope stabilization and reclamation of land slide affected areas using tea plants. Similarly, 700 GSM Open Weave Jute Geotextiles with grass reduced runoff (3.5 - 7.7\%) soil loss (2.4 $\left.\mathrm{t}^{-1} \mathrm{ha}^{-1} \mathrm{yr}^{-1}\right)$ and nutrient loss (55.7\%). As per BIS (Bureau of Indian Standard), $730 \mathrm{GSM}$ open weave jute goe-textiles is recommended for hill slop stabilization using grass species up to 90 percent slope. Grass/hedge crop establishment with jute geo-textiles can also help to environmentally sustainable landscape development in airports, parks and housing estates. It is also proved that the mass eroded land and areas affected by natural calamities can be rehabilitated by vegetation establishment using jute geo-textile. Thus, it is the high time to review the policy interventions in all developmental activities of various departments to include the vegetation establishment using jute geo-textiles as an eco-friendly slope stabilization measures.
\end{abstract}

Keywords: JGT; Slopes; Land Slide

\section{Introduction}

Slope stabilisation and mass erosion control are the major challenges in the hill regions towards protecting the land from heavy land degradation, decline in the quality and quantity of water resources and disruption in the communication lines. Establishment of vegetation in the unstable slopes created due to land slide, mine waste piles, bunds of water resources and road/railway track construction is difficult due to their rickety nature and poor fertility status. Natural fibre based geo-textile (soil cover) have been most popularly used across the globe for erosion control and slope stabilization by establishing vegetation. One of the natural fibre based product in India is Jute geo-textile which is being globally used in various soil conservation applications. Wide choices of jute geotextiles are being produced and applied in diverse purposes. How- ever, standardization of types and specifications of jute geo-textiles suitable for slope stabilization had not been done so far. Hence, standardization of suitable jute-geo-textiles for slope stabilization and mass erosion control has been done in collaboration with $\mathrm{Na}$ tional Jute Board, Kolkata through set of field studies.

Standardization of jute geo-textiles for slope stabilization

ICAR - Indian Institute of Soil and Water Conservation, Regional Centre, Udhagamandalam had evaluated the various types of jute geo-textiles on runoff, soil loss, nutrient loss, soil moisture retention, nutrient build up and growth parameters of test crops and standardized the specifications of jute geo-textiles for slope stabilization. Field study on efficacy of various types of Open Weave Jute Geo-textiles namely 500, 600 and 700 GSM for slope stabilization 
on $22 \%$ slopping degraded land showed that 700 Gram per Square Metre(GSM) for Open Weave JGT is more effective in reducing runoff and soil loss, nutrient loss and increasing soil moisture retention. However, plant height and growth of tea plants were better under 500 and 600 GSM JGT. Higher biomass of grass and other herbs in between tea plants was generated by 700 GSM JGT.

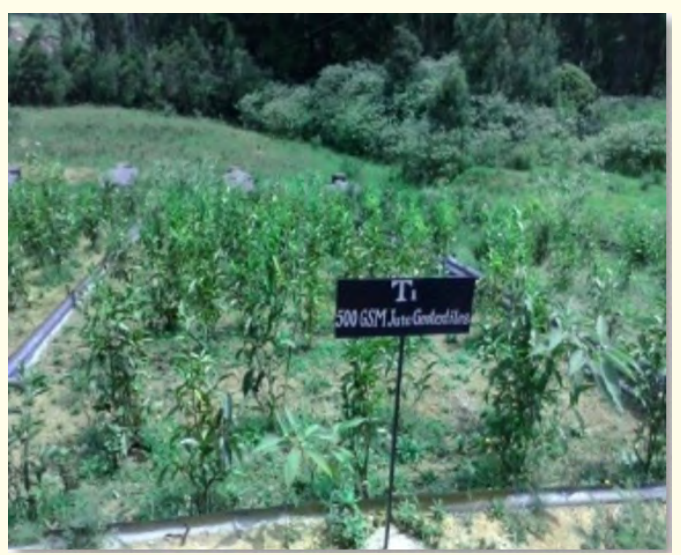

Figure a
Considering the scopes of tea cultivation in sloppy regions, rehabilitation of land slide areas using tea plants, optimal moisture requirement and better plant growth of tea plants and economics, it is suggested that 500 GSM JGT is more effective for slope stabilization with tea plants. Keeping in view of higher biomass production of grass and other herbs growing in between tea plants, 700 GSM JGT is suitable for slope stabilization with grass.

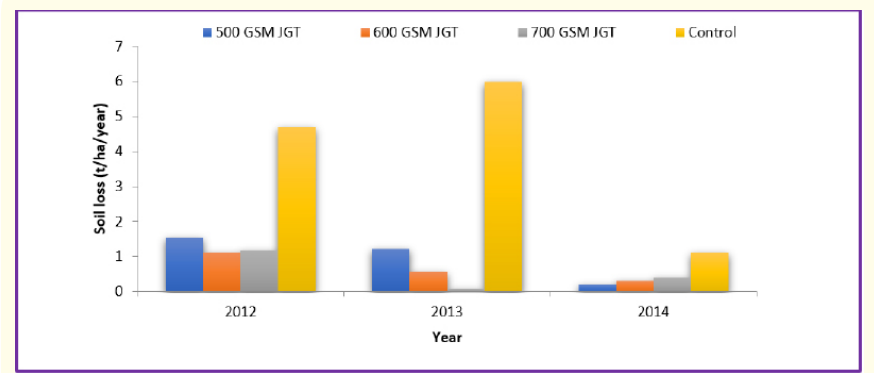

Figure 1: Effect of various open weave JGT on erosion control.

Prototype field study on efficacy of various types of Jute Geotextiles and Synthetic Geo-textiles on 60 and 90 per cent land

\begin{tabular}{|c|c|c|c|c|c|c|c|c|c|}
\hline \multirow[b]{2}{*}{ Year } & \multirow{2}{*}{$\begin{array}{c}\text { Rainfall } \\
\text { (mm) }\end{array}$} & \multicolumn{4}{|c|}{ Runoff (mm) } & \multicolumn{4}{|c|}{ Runoff (\%) } \\
\hline & & $\begin{array}{c}500 \text { GSM } \\
\text { JGT }\end{array}$ & $\begin{array}{c}600 \text { GSM } \\
\text { JGT }\end{array}$ & $\begin{array}{c}700 \text { GSM } \\
\text { JGT }\end{array}$ & Control & $\begin{array}{c}500 \text { GSM } \\
\text { JGT }\end{array}$ & $\begin{array}{c}600 \mathrm{GSM} \\
\text { JGT }\end{array}$ & $\begin{array}{c}700 \text { GSM } \\
\text { JGT }\end{array}$ & Control \\
\hline 2012 & 798.3 & 86.5 & 58.3 & 66.6 & 140.0 & 10.8 & 7.3 & 8.3 & 17.5 \\
\hline 2013 & 1142.5 & 85.0 & 69.5 & 57.1 & 174.3 & 7.4 & 6.1 & 5.0 & 15.3 \\
\hline 2014 & 1098.4 & 79.4 & 49.8 & 30.4 & 169.0 & 7.2 & 4.5 & 2.8 & 15.3 \\
\hline Mean & 1013.1 & 83.6 & 59.2 & 51.4 & 161.1 & 8.5 & 6.0 & 5.4 & 16.0 \\
\hline $\mathrm{CD}(5 \%)$ & & \multicolumn{4}{|c|}{28.17} & \multicolumn{4}{|c|}{1.69} \\
\hline
\end{tabular}

Table 1: Effect of open weave JGT under Tea plants for hill slope stabilization.

slopes shows that Jute Geo-textiles outperformed the Synthetic Geo-textiles in reduction of runoff and soil erosion. Among the Open Weave and Non Woven JGT, Open Weave JGT is more effective in reducing runoff and soil loss, nutrient loss and also increased soil moisture retention. Growth of the grass and root characters is vigorous in the plots covered by JGT as compared to Synthetic Geotextiles.

Application of Open Weave JGT increased the plant height, number of tillers, root density, surface area coverage and volume of soil binding in both the slope categories. The study concludes that the JGT can be effectively utilized for slope stabilization as compared to Synthetic Geo-textiles. Open Weave JGT with grasses is recommended for slope stabilization in the degraded land having the slopes up to $90 \%$.

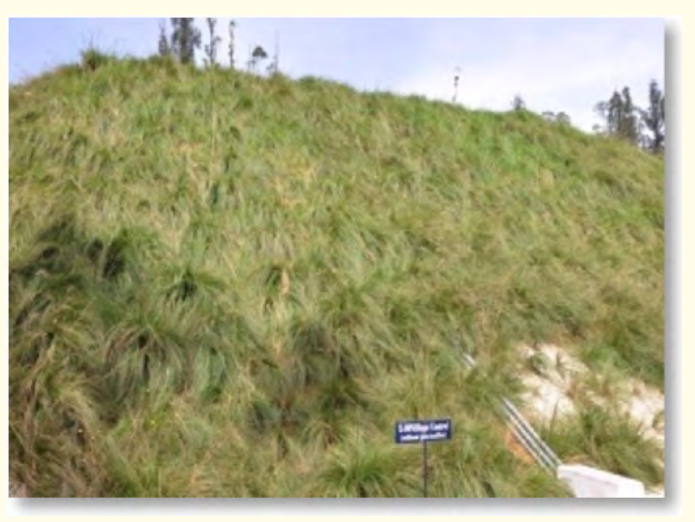

Figure b 


\begin{tabular}{|c|c|c|c|c|c|}
\hline \multirow{2}{*}{ Type of Geo textiles } & \multirow{2}{*}{ Specification } & \multicolumn{2}{|c|}{ Cost of application with grass } & \multicolumn{2}{|c|}{ Cost of application with tea } \\
\hline & & $\left(\operatorname{Rs~m}^{-1}\right)$ & $\left(\right.$ Rs ha $\left.^{-1}\right)$ & $\left(\operatorname{Rs~m}^{-1}\right)$ & (Rs ha-1) \\
\hline \multirow[t]{3}{*}{ Open weave JGT } & 500 GSM & 25.50 & $2,55,000$ & 33.50 & $3,35,000$ \\
\hline & $600 \mathrm{GSM}$ & 31.25 & $3,12,500$ & 39.25 & $3,92,500$ \\
\hline & $700 \mathrm{GSM}$ & 33.80 & $3,38,000$ & 41.80 & $4,18,000$ \\
\hline Non-woven JGT & \multirow[t]{2}{*}{$500 \mathrm{GSM}$} & 42.00 & $4,20,000$ & 50.00 & $5,00,000$ \\
\hline Non-woven Synthetic GT & & 86.14 & $8,61,400$ & 94.14 & $9,41,400$ \\
\hline
\end{tabular}

Table 2: Economics of different Jute Geo-textiles.

\section{Recommendations}

- 500 GSM Open Weave Jute Geotextiles is effective in reducing runoff ( $6.7-12.5 \%)$, soil loss $\left(3.93 \mathrm{t}^{-1} \mathrm{ha}^{-1} \mathrm{yr}^{-1}\right)$ and nutrient loss (46-62\%) and recommended for hill slope stabilization and reclamation of land slide affected areas using tea plants

- 700 GSM Open Weave Jute Geotextiles with grass reduced run off (3.5 - 7.7\%) soil loss (2.4 $\left.\mathrm{t}^{-1} \mathrm{ha}^{-1} \mathrm{yr}^{-1}\right)$ and nutrient loss (55.7\%). As per BIS (Bureau of Indian Standard), 730 GSM open weave jute goe-textiles is recommended for hill slop sta bilization using grass species up to 90 percent slope.

Potential sloping lands for application of jute geo- textiles

- Protection of slopes in road and railway embankments, bridge approaches, terraces in hilly terrains.

- Stabilization of sand dunes, mine spoils, mine dumps in open cast iron, PFA dumps in thermal power plants and slag heaps

- Rehabilitation mass eroded lands due to cyclones, earthquakes and landslides

- Lake, canal and river bank stabilization

- Slope stabilization in farm and forestry areas

- Green wards developments in parks, airports and housing estates

Potential regions for up scaling the applications of jute geotextiles

In India, about 42 million ha or $12.6 \%$ of land area, excluding snow covered area, is prone to landslide hazard. Out of this, 0.18 million sq. km falls in North East Himalaya, including Darjeeling and Sikkim Himalaya; 14 million ha falls in North West Himalaya (Uttarakhand, Himachal Pradesh and Jammu and Kashmir); 0.09 million sq. km in Western Ghats and Konkan hills (Tamil Nadu, Kerala, Karnataka, Goa and Maharashtra) and 0.01 million sq. km in Eastern Ghats of Aruku area in Andhra Pradesh. This technol- ogy can be utilized in above regions through State Department of Agricultural Engineering, National and state Highway authorities, Indian Railways, Public Works Department, Water Resources Organizations, Forestry Departments, Department of Agriculture and Horticulture and Open Cast Mining Industries [1-4].

\section{Conclusions}

Application of 500 and 700 GSM open weave jute geo-textiles with establishment of tea and grass plants, respectively is proved to be effective in stabilize the slope with reduced soil erosion. Maximum of 90 percent slope lands can be rehabilitated by application of jute geo-textiles with plantation of either tea or grass plants. Vegetation establishment using jute geo-textile in the sloppy lands on the sides of highways, railway tracks, sand dunes, mine dumps and banks of water resources will be the most economical and ecofriendly slope stabilization measures which prevent land degradation.

Grass/hedge crop establishment with jute geo-textiles can also help to environmentally sustainable landscape development in airports, parks and housing estates. It is also proved that the mass eroded land and areas affected by natural calamities can be rehabilitated by vegetation establishment using jute geo-textile.

Thus, it is the high time to review the policy interventions in all developmental activities of various departments to include the vegetation establishment using jute geo-textiles as an eco-friendly slope stabilization measures. It is recommended that necessary policy decisions should be taken to incorporate the above slope stabilization measures as mandatory in all the Central and State Government agencies including funding authorities. Appropriate policy implications on vegetation establishment using jute geo-textiles for slope management will be helpful to formulate the developmental activities as environmentally sustainable and economically viable. 


\section{Bibliography}

1. Abramson LW., et al. "Slope Stability and stabilization Methods". Wiley, New York (1995).

2. Rickson RJ. "The use of Jute Geo-textiles in Soil Erosion Control". Proc. Fifth Int. Soil Consolidation Conf., Bangkok, Thailand 5 (1988): 627-633.

3. Thomson JC and TS Ingold. Use of Jute Fabrics in Erosion Control, Report of the International Trade Centre, United Nations Conference on Trade and Development, Geneva (1986).

4. Vishnudas S., et al. "The protective and attractive covering of a vegetated embankment using coir Geo-textiles". Hydrology and Earth System Sciences Discussions, European Geosciences Union 10.4 (2006): 565-574.

Volume 3 Issue 7 July 2019

(c) All rights are reserved by $S$ Manivannan., et al. 